\title{
Isolation And Identification Of Bacteria Associated With Neonatal Septiceamia At The Specialist Hospital, Bauchi.
}

\author{
MoshoodA. Yusuf ${ }^{1}$, Tengku Haziyamin Abdul Tengku Abdul Hamid ${ }^{2}$ \\ ${ }^{1,2}$ Department of Biotechnology, Kulliyyah of Science, International Islamic University Malaysia, Bandar \\ Indera Mahkota, Jalan Istana, 25200 Kuantan, Malaysia
}

\begin{abstract}
A prospective study of neonatal septicemia undertaken at the specialist hospital Bauchi between January - March 2008 in which 101 samples were collected and analyzed. Bacterial growth was observed in 51 of the blood samples representing 50.5\%. Six genera of organisms were identified as possible causes of neonatal sepsis. Staphylococcus aureus was isolated in 39.2\% of the sample as the highest isolated while Pseudomonas aerogenosawas isolated in 3.9\% of the samples as least isolate. A distribution of the organism according to age group indicated that $47.1 \%$ organisms were isolated during the early onset sepsis ( $0-7$ days) with Escherichia coli having highest incidenceof 33.3\%, 52.9\% organisms were isolated during the late onset sepsis ( $8-28$ days) with S. aureushaving high incidenceof 51.9\%. A total of $45.1 \%$ of the organisms were isolatedin males while $54.9 \%$ organisms were isolated in females. The study indicates the neonatal septicemia is major causesof neonatal morbidity and mortality at the Specialist Hospital Bauchi
\end{abstract}

Key Word: neonatal sepsis mobility

\section{Introduction:}

Neonatal sepsis is a bacterial infection in the blood of newborns, it is a condition found in infant less than 28 days (1month) old. The cause of sepsis is related to the babies' exposure to bacteria. Sepsis that develops within the first week is usually acquired from the mother via the placenta or from passage through the birth canal. Sepsis that develops after one week is usually acquired from the child care giving environment which includeNurses, materials used during child birthespecially if not properly disinfected (Berhmanet al 2004)

Some factors related to the pregnancy or health of the mother may add to the chances that the neonate can acquire this condition, through:-

1. Complications during labourresulting in traumatic or premature delivery.

2. The mother's water has broken more than $18 \mathrm{hrs}$ prior to giving birth.

3. The mother has fever or other infection while in labour(Berhmanet al 2004).

Septicemia is fatal in about one in four cases because of the effects of large numbers of multiplying bacteria and the toxins they release into blood, newborns and the very elderly usually are at increased risk of this condition (Cheesbrough 2000).

Neonatal septicemia accounts for $7.6 \%$, of neonatal mortality in Ibadan, $5.8 \%$ in Ilorin and $14.3 \%$ in Sokoto (Azubuike et al 1999). A study of incidence at the Obafemi Awolowo University Teaching Hospital IleIfe categorized neonatal sepsis at high risk of 55\% (Ako-Naiet al 1999).

In $85 \%$ of the cases, symptoms of neonatal sepsis present within 24hrs of birth and in almost all cases, they will be present within 48hrs of birth, (Berhmanet al 2004). Clinical symptoms include fever, chills, toxicity, jaundice, poor feeding from breast or bottles, decreased or absence of urination etc. (Cheesbrough 2004)

Most etiological agents include: Group B Streptococci, Escherichia coli K1. Listeria monocytogenes, coagulase negative Staphylococcus, Klebsiella spp, Salmonella spp etc. (Berhman et al 2004, Cheesbrough 2004).

The aim of this study is:

1. To isolate and identify the etiological agents associated with neonatal sepsis at Specialist Hospital Bauchi.

2. To provide baseline information for further studies of this condition at the Specialist Hospital Bauchi.

\section{SAMPLE COLLECTION}

\section{Methodology}

$2 \mathrm{ml}$ each of one hundred and one (101) blood samples were collected from patients clinically manifested to have neonatal sepsis from the pediatric ward of the specialist hospital Bauchi via venous puncture. This was dispensed immediately and aseptically into sterile $10 \mathrm{ml}$ brain-heart infusion broth.

All collected samples were immediately processed.

The media used were prepared according to manufacturer's instruction. Each collected sample in brainheart infusion bothwas incubated immediately at 370c for 18-24 hrs. Samples were then examined for visible 

signs of bacterial growth which includes turbidity above the red cell level, heamolysis, clots etc. The resulting broth cultures were sub cultured onto chocolate and MacConkey agar, then incubated for $18-24 \mathrm{hrs}$.at $37 \mathrm{oC}$. In the absence of growth, this process was repeated twice at intervals of 2 days before sepsis was ruled out. Growths in the form of discrete colonies were examined as described by Cheesbrough (2000).

Isolated bacteria were identified based on morphological characteristics, Gram's stain reaction and biochemical test. Results were confirmed using manual for determinative bacteriology, (Cheesbrough 2000).

Preliminary identification was done by growth characteristic, colonial morphology such as size of colonies, heamolysis,color, (Cheesbrough 2000).

All growth obtained from the sub-cultured media were stained by Gram's Method.

All Gram-positive cocci organism were identified by catalase and coagulase test. While Gram negative organisms were subjected to the following tests: motility, Indole, urease, citrate utilization test, triple sugar iron test. As described by Cowan and steel (1965) and (Cheesbrough, (2000).

\section{Results}

One hundred and one blood samples were collected from septic neonates. Of these (50.5\%) were confirmed cases of neonatal septicemia as shown in Table 1 which represents the isolated organism and biochemical tests employed in identification. Staphylococcus aureus was isolated in 20 samples representing $39.2 \%$ as the highest isolated organism, while the least organism isolated was Pseudomonas aerogenosain 2 representing $3.9 \%$ as shown in Table 2.

Table 3 shows a distribution of isolated organismaccording to age group, 24 organismrepresenting $47 \%$ were isolated during the early onset sepsis and 27 organismrepresenting $52.9 \%$ were isolated during late onset sepsis. Table 4 shows that of the confirmed cases of septicemia (45.1\%) were males and (54.9\%) were females.

Table 1. Biochemical characteristics of isolated organisms

\begin{tabular}{|c|c|c|c|c|c|c|c|c|c|c|c|c|}
\hline Organism & $\begin{array}{l}\text { Gram' } \\
\mathrm{s} \\
\text { reactio } \\
\mathrm{n}\end{array}$ & $\begin{array}{l}\text { Catalas } \\
\mathrm{e}\end{array}$ & $\begin{array}{l}\text { Coa } \\
\text { gula } \\
\text { se }\end{array}$ & $\begin{array}{l}\text { Ureas } \\
\mathrm{e}\end{array}$ & $\begin{array}{l}\text { Citrat } \\
\mathrm{e}\end{array}$ & $\begin{array}{l}\text { Moti } \\
\text { lity }\end{array}$ & Indole & $\begin{array}{l}\text { Slo } \\
\text { pe }\end{array}$ & Butt & $\begin{array}{l}\mathrm{H} 2 \\
\mathrm{~S}\end{array}$ & Gas & $\begin{array}{l}\text { Freque } \\
\text { ncy }\end{array}$ \\
\hline Staphylococcus aureus & $+\mathrm{C}$ & + & + & NA & NA & NA & NA & NA & NA & NA & NA & 20 \\
\hline Staphylococcus spp & $+\mathrm{C}$ & + & - & NA & NA & NA & NA & NA & NA & NA & NA & 4 \\
\hline $\begin{array}{l}\alpha \\
\text { heamolyticStreptococc } \\
\text { us spp }\end{array}$ & $+\mathrm{C}$ & - & - & NA & NA & NA & NA & NA & NA & NA & NA & 8 \\
\hline Escherichia coli & $-\mathrm{R}$ & NA & NA & - & - & + & + & $\mathrm{Y}$ & $\mathrm{Y}$ & - & + & 10 \\
\hline Klebsiella pneumonia & $-\mathrm{R}$ & NA & NA & + & + & - & - & $\mathrm{Y}$ & $\mathrm{Y}$ & - & + & 4 \\
\hline Salmonella typhi & $-\mathrm{R}$ & NA & NA & - & - & + & - & $\mathrm{Re}$ & $\mathrm{Y}$ & + & - & 3 \\
\hline $\begin{array}{l}\text { Pseudomonas } \\
\text { aerogenosa } \\
\text { Total }\end{array}$ & $-\mathrm{R}$ & NA & NA & & & + & & & & & & $\frac{2}{51}$ \\
\hline
\end{tabular}

Key

C - Cocci

R - Red

Y Yellow

Re - Red

NA - Not applicable

Table 2 - Distribution of isolated organism and their respective percentage occurrence.

\begin{tabular}{|l|l|l|l|}
\hline Organism & Gram stain reaction & Number & Percentage occurrence $(\%)$ \\
\hline Staphylococcus aureus & Positive Cocci & 20 & 39.2 \\
\hline Staphylococcus spp & Positive Cocci & 4 & 7.8 \\
\hline$\alpha$-heamolyticStreptococcus spp & Positive Cocci & 8 & 15.7 \\
\hline Escherichia coli & Negative Rod & 10 & 19.6 \\
\hline Klebsiella pneumonia & Negative Rod & 4 & 7.8 \\
\hline Salmonella typhi & Negative Rod & 3 & 6.0 \\
\hline Pseudomonas aerogenosa & Negative Rod & 2 & 3.9 \\
\hline Total & & 51 & 100 \\
\hline
\end{tabular}

Key: Spp: Species

$\%$ occurrence of Gram positive organism 
Isolation And Identification Of Bacteria Associated With Neonatal Septiceamia At The Specialist $32 \times 100=62.8 \%$

51

$\%$ occurrence of Gram negative organism

$19 \times 100=37.2 \%$

51

Table 3:- Relative proportion of isolated organisms that were identified at each stage of age group *

\begin{tabular}{|l|l|l|l|l|l|}
\hline \multirow{2}{*}{ Organism } & \multirow{2}{*}{ Total } & \multicolumn{2}{l|}{ Early onset sepsis (0-7days) } & \multicolumn{2}{l|}{$\begin{array}{l}\text { Late onset sepsis }(8-28 \\
\text { days })\end{array}$} \\
\cline { 3 - 6 } & & No & $\%$ & No & $\%$ \\
\hline Staphylococcus aureus & 20 & 6 & 25 & 14 & 51.9 \\
\hline Staphylococcus spp & 4 & 1 & 4.2 & 3 & 11.1 \\
\hline $\begin{array}{l}\alpha \text {-heamolytic } \\
\text { Streptococcus spp }\end{array}$ & 8 & 4 & 16.7 & 4 & 14.8 \\
\hline Escherichia coli & 10 & 8 & & & \\
\hline Klebsiella pneumonia & 4 & 3 & 33.3 & 2 & 7.4 \\
\hline Salmonella typhi & 2 & 2 & 12.5 & 1 & 3.7 \\
\hline Pseudomonas aerogenosa & 3 & - & 8.3 & 1 & 3.7 \\
\hline Total & & 24 & - & 2 & 7.4 \\
\hline
\end{tabular}

* Vertical comparison only

Table 4:- Distribution of Isolated organism according to Gender

\begin{tabular}{|l|l|l|l|l|l|l|}
\hline Organism & Total & & Male & $\%$ & Female & $\%$ \\
\hline Staphylococcus aureus & 20 & & 9 & 17.7 & 11 & 21.6 \\
\hline Staphylococcus spp & 4 & & 3 & 5.8 & 1 & 2.0 \\
\hline $\begin{array}{l}\alpha- \\
\text { heamolyticStreptococcus } \\
\text { spp }\end{array}$ & 8 & 2 & 4.0 & 6 & 11.7 \\
\hline Escherichia coli & 10 & & & & & \\
\hline Klebsiella pneumonia & 4 & 3 & 3 & 5.8 & 7 & 13.6 \\
\hline Salmonella typhi & 3 & 3 & 5.8 & 1 & 2.0 \\
\hline Pseudomonas aerogenosa & 2 & 2 & 4.0 & 1 & 2.0 \\
\hline Total & 51 & 1 & 2.0 & 1 & 2.0 \\
\hline
\end{tabular}

\section{Discussion}

A prospective study of neonatesepticemia undertaken at the specialist hospital Bauchi between January - March 2008 in which 101 samples was collectedand analyzed.

Out of these, 51 samples yielded 6 genera of organisms placing the incidence rate of neonatal sepsis at the center at $51(50.5 \%)$. This may be attributed to the poor obstetric care and unsterile delivery practices, it may also be attributed to exposure to contaminated hospital equipment, having catheters in blood vessel for a long period and staying in the hospital for a long period. This agrees with the report of Ako-Naiet al (1990) which categorized the incidence at high risk of 55\%. A study undertaken by Mokuolu et al (2002) reported an incidence rate of $30.8 \%$. Ojukwuet al (2002) reported onincidence rateof $23.8 \%$ in south eastern Nigeria attributing the predisposing factors to prolonged/obstructed labour, home/traditional birth, contaminating birth equipment and child caring environment.

Table 2 shows that Staphylococcus aureus was the most common pathogen accounting for 20 representing $39.2 \%$ of the total isolates. This may be attributed to the fact that $\mathrm{S}$. aureusis a common cause of infection particularly nosocomialinfection. Similar results were reported by Mokuolu et al (2002) 29.5\%, Ojukwu et al (2002) 45\% Ako-Naiet al (1999) 33.8\%. Escherichia coli were the predominant Gram negative organism accounting for $10(19.6 \%)$ of the isolates. This may be attributed to the fact that E. coliis most common Gram negative organism associated with infections. Similar results were reported by Ojukwu et al (2002) 18.2\%. In contrast Al-Zwaini (2002) reported Klebsiella pneumonia to be most common Gram negative organism (30\%) seconded by E. coli(21\%). Mokuoluet al (2002) also reported K. pneumoniato be most common Gram negative organism (16.4\%). The lower Incidence of streptococcus sppin this study $8(15.7 \%)$ is in agreement with reports from many developing countries, Dawudo et al (1997), Haque et al (1990), Ojukwu et al (2002). Pseudomonas aerogenosaaccounting for $2(3.9 \%)$ which may have been acquired through the respiratory tract in patients requiring mechanical ventilation had the lowest incidence similar to reports by Al-Zwaini (2002). 
Other results incuse- coaguasenegative Staphylococcus $\operatorname{spp}(\mathrm{CON})$ accounting for $4(7.8 \%)$ isolates, which may be attributed to the fact that CoNS which are common commensalswith little pathogenicity, premature neonates are particularly susceptible to invasive infection. Salmonella typhiaccounting for $3(6.0 \%)$ of isolates is an emerging pathogen

Neonatal bacterial sepsis has been categorized into early onset sepsis 0-7 days presumed to be from mother to child and late onset sepsis 8-28days presumed to be from child care giving environment. Table 3 shows a distribution of isolated organism's according to these categorized age groups. Gram negative organisms as a group werethe commonest organisms isolated in early onset sepsis with distribution of 13/24 (54.1\%), E colibeing predominant $8(33.3 \%)$ of isolates. This may be attributed to infestation of the placenta tissue and amniotic fluid, rupture of membrane that last longer than 24hours and frequent vaginal examination during labourleading to infestation Mendel et al (2005, while Staphylococcus aureus accounted for 6/24 (25\%) of isolated organism S. aureuswas the most associated tolate onset sepsis accounting for 14/27 (51.9\%) of isolated organisms, this may be attributed to the fact that $\mathrm{S}$. aureusis most common causeof nosocomial infection via skinand deep seated tissue abscess, exposure to contaminated hospital equipment, catheters in blood vessel, Schrag (2005). Gram negative organism collectively accounted for 4/27 (22.2\%). Similar results were reported by Mokuolu et al (2002), Al-Zwaini (2002). Generally 24/51 (47.1\%) was isolated at early onset sepsis while $27 / 51(52.9 \%)$ accounted for late onset sepsis.

TABLE 4 shows a distribution of isolated organisms based on gender, S.aureuswas mostly predominant in males and females and P. aerogenosawas least predominant in males and females. A total of $23 / 51$ (45\%) was recorded in males while $28 / 51$ (54.9\%) was recorded in females. This may be attributed to the feet that males have a stronger immune response to that of the females.

\section{References}

[1] Ako-Nai AK, Taiwo O, Ebri A, Adeniran MO. Bacterial isolates involved in cases of septicaemiain a Nigerian hospital. East AfrMedJ. 1990 Jun;67(6):407-412.

[2] Ako-Nai, A.K.; Adejuyigbe J. Ajayi V. OnipedeM. (1999). The bacteriology of neonatal septicemia in Ile-Ife, Nigeria. Journal of Tropical Pediatrics 45(3) 146-151.

[3] Al-Zwaini E.J.K. (2002) Neonatal septicemia in the neonatal care unit, Al-Anbar governorate, Iraq. Eastern Mediterranean Health Journal. 7-20-29

[4] AzubuikeJ.C. NkanginiemeK.E.O (1999). Pediatrics and child health in a Tropical region pp.24. African Educational Service, Owerri Nigeria.

[5] Berhman R.E, Kligman R.M. Arvin A.M (2004) Textbook of Pediatrics 16th ed. W.B Saunders Company Toronto.

[6] Cheesbrough(2000): District laboratory practice in tropical countries. Part 2 pp. $124-125$ Royal society forchemistry

[7] Cowan, S. T. \& Steel, K. J.(1965).Manual for the Identification of Medical Bacteria. London: Cambridge University Press

[8] Dawodu, A.H and ALausa O.K (1997) Neonatal Septicemia in the tropics. African Journal of Medicine and Medical Science. 9:1-6

[9] Haque K.N, Chagai A.H, Saheed M.M (1990) half a decade of neonatal sepsis, Riyadh, Saudi Arabia. Journal of tropical pediatrics $36: 20-3$

[10] Mendel G.C, Benneth J.E, Dollin R. (2005) Principle and practiceOf infectious Disease 6th ed. London Churchill Livingstone

[11] MokuoluA. D, Jiya N, Adesigun (2002) Neonatal Septicea in Ilorin; bacterial pathogens and attribute sensitivity pattern. East African Medical Journal.

[12] Ojukwu J.U Aboyi L.E, Ugwu J, Orji I. K. (2002) Neonatal Septicemia in Imprerisk bodies in South - Eastern Nigeria Publication of Medicine.

[13] Schrag S. (2005) Prevention of Neonatal Sepsis Clinical Perinatology. 